\title{
Syntheses, Spectral, Surface Morphological and Gamma Ray Irradiation Studies of Some Oxomolybdenum(V) and Dioxomolybdenum(VI) Complexes of an Azo Dye Derived from 4-aminoantipyrine
}

\author{
M. L. Harikumaran Nair* and Anju. S. Appukuttan \\ Department of Chemistry, University College, Thiruvananthapuram-695034, Kerala, India. \\ *E-mail: drmlhnair@gmail.com
}

(Received January 26, 2012; Accepted February 20, 2012)

\begin{abstract}
Syntheses of some novel oxomolybdenum(V) and dioxomolybdenum(VI) complexes with an azo dye methoxyphenolazoantipyrine (HL) derived from 4-aminoantipyrine and 2-methoxyphenol are reported. The complexes have been characterized by elemental analyses, molar conductance, magnetic susceptibility data, IR, UV-Vis, ${ }^{1} \mathrm{H}$ NMR, EPR and FAB mass spectral studies. The physicochemical studies and spectral data indicate that HL acts as a bidentate chelating ligand. The complexes have the general formulae $\left[\mathrm{MoO}(\mathrm{HL}) \mathrm{XCl}_{2}\right]$ and $\left[\mathrm{MoO}_{2}(\mathrm{HL}) \mathrm{XCl}\right]$, where $\mathrm{X}=\mathrm{Cl}, \mathrm{NCS}$ or $\mathrm{NO}_{3}$. All the complexes are found to have distorted octahedral geometry. Structural and morphological characterization of the complexes $\left[\mathrm{MoO}(\mathrm{HL}) \mathrm{Cl}_{3}\right](1)$ and $\left[\mathrm{MoO}_{2}(\mathrm{HL}) \mathrm{Cl}_{2}\right](4)$ before and after gamma ray irradiation, was performed by X-ray diffraction and scanning electron microscopy(SEM).The ligand and the complexes were screened for their possible antimicrobial activities.
\end{abstract}

Key words: Oxomolybdenum(V), Dioxomolybdenum(VI), 4-Aminoantipyrine, Spectral studies, $\gamma$-Irradiation

\section{INTRODUCTION}

Molybdenum is a biologically important trace element that occurs in the redox active sites of molybdoenzymes involved in nitrogen, sulfur or carbon metabolism. ${ }^{1}$ Recent years have witnessed a phenomenal growth in the coordination chemistry of high valent oxomolybdenum complexes owing to their potential applications..$^{2-6}$ The 'oxotype' molybdoenzymes, which possess a common molybdenum cofactor and catalyze biological two electron reactions that involve a change in the number of oxygen atoms in the substrate. ${ }^{7}$ Molybdenum is a versatile transition element because it possesses a large number of stable and accessible oxidation states as well as coordination numbers. The formal oxidation state of molybdenum fluctuates between +6 and +4 via a +5 intermediate during turnover. ${ }^{8} \mathrm{~A}$ variety of chemical reactions are catalyzed by the molybdenum coordination complexes. ${ }^{9}$

Herein, we report the synthesis, spectral characterization, thermal and antibacterial studies of complexes of oxomolybdenum(V) and dioxomolybdenum(VI) species with a potentially bidentate ligand derived from 4-aminoantipyrine and 2-methoxyphenol. The irradiation may induce changes in textural, structural, electric, thermal and magnetic properties of a large variety of solids. ${ }^{10,11}$ Literature survey revealed that spectral and X-ray diffraction studies of irradiated salts as well as metal complexes are limited. ${ }^{12}$ Knowledge regarding the radiation effect benefit the development of advanced material in various fields. Moreover, since studies concerning the effect of $\gamma$-radiation on transition metal complexes are rare, the effect of $\gamma$-radiation on X-ray diffraction and surface morphology of two of the complexes have also been incorporated in the present investigation.

\section{EXPERIMENTAL}

\section{Materials and Physical Measurements}

Molybdenum pentachloride (Alfa Aesar, Lancaster, UK) and molybdenum trioxide (Loba Chemie, Mumbai, India) were used. All other chemicals were of AR grade.

Metal and chloride were estimated by standard methods. ${ }^{13}$ The elemental analyses (C, H, N and S) were carried out at the Sophisticated Test and Instrumentation Center (STIC), Kochi. Room temperature molar conductance of the complexes in methanol was recorded on Elico direct reading conductivity meter at a concentration of $\sim 10^{-3} \mathrm{M}$. The magnetic susceptibilities were recorded at room temperature by Gouy method. Diamagnetic corrections for various atoms and structural units were computed using Pascal's constants. ${ }^{14}$ The IR spectra $\left(\mathrm{KBr}, \mathrm{cm}^{-1}\right)$ of ligand and complexes were recorded in the region $4000-400 \mathrm{~cm}^{-1}$ on Perkin-Elmer 397 Spectrophotometer. Electronic absorption spectral measurements of the com- 
plexes in methanol were conducted using Jasco-V-550UV-Vis spectrophotometer. ${ }^{1} \mathrm{H}$ NMR spectra of the ligand, $\mathrm{HL}$ and the complex 4 were recorded on a $300 \mathrm{MHz}$ FT NMR instrument using TMS as reference. The FAB mass spectrum of ligand $\mathrm{HL},\left[\mathrm{MoO}(\mathrm{HL}) \mathrm{Cl}_{3}\right](1)$ and $\left[\mathrm{MoO}_{2}(\mathrm{HL})\right.$ $\mathrm{Cl}_{2}$ ](4) were recorded in a JEOL JMS600H mass spectrometer at NIIST, Thiruvananthapuram, India. EPR spectra of the complex 1 in solid state at LNT was recorded on a Varian E-112 Spectrometer at X-band, using TCNE as marker with $100 \mathrm{kHz}$ modulation frequency and $9.1 \mathrm{GHz}$ microwave frequency at the SAIF, IIT, Mumbai, India. Thermal studies were carried out by heating in air at a rate of $10{ }^{\circ} \mathrm{C} / \mathrm{min}$ on a Perkin Elmer, Diamond TG/DTA Analyser. X-ray powder diffraction patterns of unirradiated and irradiated samples were recorded using Philips X-ray PW1710 diffractometer using nickel filter $\left(\mathrm{Cu}-\mathrm{K}_{\alpha}\right.$ radiation $\lambda=1.5406$ ). Surface morphological study of unirradiated and irradiated samples were recorded using JEOL Model JSM-6390LV. The samples were subjected to gamma irradiation to a dose of $800 \mathrm{kGy}$ using ${ }^{60} \mathrm{Co} \gamma$-ray in Gamma chamber $5000 \mathrm{cc}$ self shielded at constant intensity under room temperature at a dose rate of $1.85 \mathrm{kGy} \mathrm{h}^{-1}$.

\section{Synthesis of Ligand (HL)}

Synthesis of ligand, $\mathrm{HL}\left(\mathrm{C}_{18} \mathrm{H}_{18} \mathrm{~N}_{4} \mathrm{O}_{3}\right)$ in Fig. 1 was carried out by 4-aminoantipyrine and 2-methoxyphenol by diazotization and coupling as reported earlier. ${ }^{15}$ Purity of the ligand was tested by TLC. It was characterized by IR, UV and ${ }^{1} \mathrm{H}$ NMR spectroscopy. m.p. $231{ }^{\circ} \mathrm{C}$.

\section{Synthesis of Oxomolybdenum(V) Complexes}

The chloride complex was prepared by adding a methanolic solution of $\mathrm{MoCl}_{5}(2 \mathrm{mmol}, 20 \mathrm{~mL})$ in small quantities with stirring to a hot methanolic solution of the ligand $(2 \mathrm{mmol}, 20 \mathrm{~mL})$. The solution formed was refluxed for 2-3 $\mathrm{h}$. The precipitated complexes were filtered, washed with aqueous methanol and dried over $\mathrm{P}_{4} \mathrm{O}_{10}$ in vacuo.

The following general method was adopted for the preparation of thiocyanate and nitrate complexes. ${ }^{12}$ A methanolic solution of $\mathrm{MoCl}_{5}(2 \mathrm{mmol}, 20 \mathrm{~mL})$ containing $2 \mathrm{mmol}$ of

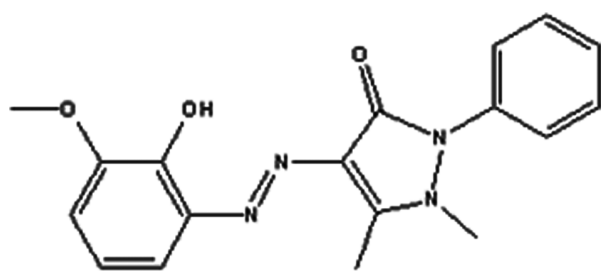

Fig. 1. Tentative structure of Ligand HL.
$\mathrm{NH}_{4} \mathrm{CNS} / 2$ mmol $\mathrm{LiNO}_{3}$, was added to a hot methanolic solution of the ligand $(2 \mathrm{mmol}, 20 \mathrm{~mL})$. The thiocyanate complex was precipitated on heating the mixture at $40^{\circ} \mathrm{C}$ for $\sim 30 \mathrm{~min}$, while the nitrate complex was precipitated on refluxing the solution for 2-3 $\mathrm{h}$. The precipitated complexes were suction filtered, washed with aqueous methanol (1:1) followed by dry ether and then dried over $\mathrm{P}_{4} \mathrm{O}_{10}$ in vacuo.

\section{Synthesis of Dioxomolybdenum (VI) Complexes}

$\mathrm{MoO}_{3}(2 \mathrm{mmol})$ was dissolved in minimum amount of hot conc. $\mathrm{HCl}(4 \mathrm{~mL})$. Methanolic solution of this was added dropwise with stirring to a methanolic solution of the ligand $(2 \mathrm{mmol}, 20 \mathrm{~mL})$. The solution formed was refluxed for 2-3 h. The solid separated was suction filtered, washed first with aqueous methanol, then with ether and dried over $\mathrm{P}_{4} \mathrm{O}_{10}$ in vacuo. The thiocyanate and nitrate complexes were prepared in the same manner as the oxomolybdenum(V) complexes.

\section{Antimicrobial Study}

Antitubercular activity of HL and complexes against $M$. tuberculosis $\mathrm{H} 37 \mathrm{Rv}$ and antibacterial activity against Escherichia coli and Lactobacillus leichmannii were done by the Resazurin assay method at the Rajeev Gandhi Centre for Biotechnology (Thiruvananthapuram).

\section{RESULTS AND DISCUSSIONS}

\section{Analytical Measurements}

All the complexes are deeply coloured and fairly stable at room temperature. They are non hygroscopic solids and soluble in common organic solvents, like acetone, chloroform, methanol, acetonitrile, DMF and DMSO. Formulation of these complexes have been done on the basis of their elemental analytical data, molar conductance and magnetic susceptibility measurements. The analytical data show that all the complexes are mononuclear with the general formulae $\left[\mathrm{MoO}(\mathrm{HL}) \mathrm{Cl}_{2} \mathrm{X}\right]$ and $\left[\mathrm{MoO}_{2}(\mathrm{HL}) \mathrm{ClX}\right]$, where $\mathrm{X}=\mathrm{Cl}, \mathrm{NCS}, \mathrm{NO}_{3}$. The molar conductances of the complexes in methanol is in the range of $3.6-14.8 \mathrm{ohm}^{-1} \mathrm{~cm}^{2}$, adequately confirming the non electrolytic nature of the complexes. ${ }^{16}$

\section{Magnetic Susceptibilities}

The magnetic susceptibility values of all the oxomolybdenum $(\mathrm{V})$ complexes at room temperature are near the spin-only value (1.73 B.M.) as expected of a $\mathrm{d}^{1}$ system. This shows the absence of Mo-Mo interaction in these com- 
Table 1. Analytical data of the ligand and complexes

\begin{tabular}{|c|c|c|c|c|c|c|c|c|c|}
\hline \multirow{2}{*}{ Ligand/Complexes } & \multirow{2}{*}{$\begin{array}{c}\text { Yield } \\
(\%)\end{array}$} & \multicolumn{6}{|c|}{ Composition \% found (calc) } & \multirow{2}{*}{$\lambda_{\mathrm{m}}{ }^{\mathrm{a}}$} & \multirow{2}{*}{$\mu_{\mathrm{eff}}^{\mathrm{b}}($ B.M. $)$} \\
\hline & & Mo & Carbon & Hydrogen & Nitrogen & Chlorine & Sulphur & & \\
\hline $\mathrm{HL}$ & 75 & - & 68.56(68.35) & $5.89(6.02)$ & 11.64(11.95) & - & - & - & - \\
\hline$[\mathrm{MoO}(\mathrm{HL}) \mathrm{C}$ & 82 & $17.08(17.23)$ & $38.50(38.84)$ & $3.18(3.26)$ & $10.01(10.06)$ & $18.96(19.11)$ & - & 11.2 & 1.67 \\
\hline$\left[\mathrm{MoO}(\mathrm{HL}) \mathrm{Cl}_{2}(\mathrm{NCS})\right](2)$ & 78 & $16.28(16.5$ & $39.24(39.39)$ & $3.04(3.13)$ & $11.82(12.08)$ & $12.08(12.2$ & $5.21(5.53)$ & 5.6 & 1.63 \\
\hline$\left[\mathrm{MoO}(\mathrm{HL}) \mathrm{Cl}_{2}\left(\mathrm{NO}_{3}\right)\right]$ (3) & 74 & $16.34(16.45)$ & $36.84(37.06)$ & $2.98(3.11)$ & $11.78(12.01)$ & $11.98(12.16)$ & - & 13.4 & 1.68 \\
\hline$\left[\mathrm{MoO}_{2}(\mathrm{HL}) \mathrm{Cl}_{2}\right](4)$ & 84 & $17.46(17.85)$ & $40.01(40.24)$ & $3.18(3.38)$ & $10.17(10.43)$ & $12.96(13.20)$ & - & 7.4 & diamagnetic \\
\hline$\left[\mathrm{MoO}_{2}(\mathrm{HL})(\mathrm{NCS})_{2}\right](5)$ & 80 & $16.24(16.47)$ & $39.68(41.24)$ & $2.82(3.11)$ & $14.26(14.43)$ & - & $10.95(11.01)$ & 6.6 & diamagnetic \\
\hline$\left[\mathrm{MoO}_{2}(\mathrm{HL}) \mathrm{Cl}\left(\mathrm{NO}_{3}\right)\right](6)$ & 77 & $16.82(17.02)$ & $37.87(38.36)$ & $3.06(3.22)$ & $11.98(12.43)$ & $6.12(6.29)$ & - & 5.8 & diamagnetic \\
\hline
\end{tabular}

${ }^{a}$ Molar conductivity, $10^{-3} \mathrm{M}$ Methanol at $298 \mathrm{~K}$.

${ }^{\mathrm{b}}$ Magnetic susceptibility per metal atom.

plexes. The presence of $\mathrm{Mo}=\mathrm{O}$ bond in oxomolybdenum $(\mathrm{V})$ complexes produce strong tetragonal distortion and this may cause reduction in magnetic moment values. The high spin orbit coupling constant ${ }^{17}$ of Mo $\left(\lambda=1000 \mathrm{~cm}^{-1}\right)$ also lowers the $\mu_{\text {eff }}$ value. All the dioxomolybdenum (VI) complexes are found to be diamagnetic as expected for a $\mathrm{d}^{0}$ system. The analytical data are presented in Table 1.

\section{Infraed Spectra}

Important infrared spectral bands of the ligand and complexes and their tentative assignments are given in Table 2. In all the complexes ligand coordinates through carbonyl oxygen and one of the nitrogens of the diazo group as evidenced by the shift of $v_{\mathrm{C}=\mathrm{O}}$ and $v_{\mathrm{N}=\mathrm{N}}$ to lower frequencies. ${ }^{18}$ The spectrum of the ligand HL exhibits a broad medium band at $2925 \mathrm{~cm}^{-1}$ is assigned to hydrogen bonded $\mathrm{OH}$ group. This band disappears in the spectra of all the complexes and a broad medium intensity band observed at $\sim 3450 \mathrm{~cm}^{-1}$, confirming the presence of free $\mathrm{OH}$ group and their non participation in coordination with the metal ion. ${ }^{15}$

Dioxomolybdenum (VI) complexes display two $\mathrm{Mo}=\mathrm{O}$ stretches at $\sim 936-942 \mathrm{~cm}^{-1}$ and at $\sim 906-910 \mathrm{~cm}^{-1}$ due to symmetric and antisymmetric stretching of cis $-\mathrm{MoO}_{2}^{2+}$ core. The $\mathrm{MoO}_{2}^{2+}$ prefers to form a cis configuration due to maximum utilization of the $d \pi$ groups. A very strong band observed at $\sim 960 \mathrm{~cm}^{-1}$ in the spectra of oxomolybdenum complexes corresponds to $\mathrm{Mo}=\mathrm{O}$ stretching frequency. ${ }^{3}$ New weak bands at $\sim 590 \mathrm{~cm}^{-1}$ and at $\sim 440 \mathrm{~cm}^{-1}$ in the metal complexes have been assigned to $\mu_{\mathrm{Mo}-\mathrm{O}}$ and $\mu_{\text {Mo-N }}$ modes respectively. ${ }^{19}$ The N-coordinated nature of the thiocyanate group is indicated by the bands at $\sim 2060 \mathrm{~cm}^{-1}$ $\left(\mu_{\mathrm{C}-\mathrm{N}}\right), \sim 840 \mathrm{~cm}^{-1}\left(v_{\mathrm{C}-\mathrm{S}}\right)$ and $\sim 490 \mathrm{~cm}^{-1} \delta_{(\mathrm{NCS})}$. The IR spectra of the nitrate complexes suggest ${ }^{20}$ monocoordination of the nitrate group $v_{4}$ at $\sim 1490 \mathrm{~cm}^{-1}, v_{1}$ at $\sim 1380 \mathrm{~cm}^{-1}$ and $v_{2}$ at $\sim 1034 \mathrm{~cm}^{-1}$.

\section{Electronic Spectra}

The electronic absorption bands of bidentate azo dye ligand (HL) and the oxomolybdenum (V) complexes were recorded in methanol. The electronic spectrum of the ligand shows an intense band at $249 \mathrm{~nm}$ and a band of less intensity at $322 \mathrm{~nm}$ due to $\pi \rightarrow \pi^{*}$ and $n \rightarrow \pi^{*}$ transitions respectively. These bands suffer marginal shifts on complexation. The electronic spectra of the complexes showed a red shift to $\sim 256 \mathrm{~nm}$ and $\sim 334 \mathrm{~nm}^{21}$

The electronic spectra of octahedral oxomolybdenum (V) complexes usually exhibit three distinct bands in the region $690-740 \mathrm{~nm}, 450-520 \mathrm{~nm}$ and $380-440 \mathrm{~nm}$, assignable to ${ }^{2} \mathrm{~B}_{2} \rightarrow{ }^{2} \mathrm{E}(d x y \rightarrow d x z, d y z),{ }^{2} \mathrm{~B}_{2} \rightarrow{ }^{2} \mathrm{~B}_{1}\left(d x y \rightarrow d_{x}^{2}-y^{2}\right)$

Table 2. Important IR data of ligand and its metal complexes

\begin{tabular}{lccccc}
\hline \multirow{2}{*}{ Ligand/Complexes } & \multicolumn{5}{c}{$\mathrm{IR}$ data $\left(\mathrm{cm}^{-1}\right)$} \\
\cline { 2 - 5 } & $\nu \mathrm{O}-\mathrm{H}$ & $\nu \mathrm{C}=\mathrm{O}$ & $v \mathrm{~N}=\mathrm{N}$ & $v_{\mathrm{s}} \mathrm{Mo}=\mathrm{O}$ & $v_{\mathrm{a}} \mathrm{Mo}=\mathrm{O}$ \\
\hline $\mathrm{HL}$ & 2925 & 1634 & 1465 & - & - \\
{$\left[\mathrm{MoO}(\mathrm{HL}) \mathrm{Cl}_{3}\right](1)$} & 3436 & 1585 & 1452 & 958 & - \\
{$\left[\mathrm{MoO}(\mathrm{HL}) \mathrm{Cl}_{2}(\mathrm{NCS})\right](2)$} & 3392 & 1592 & 1450 & 960 & - \\
{$\left[\mathrm{MoO}(\mathrm{HL}) \mathrm{Cl}_{2}\left(\mathrm{NO}_{3}\right)\right](3)$} & 3462 & 1587 & 1454 & 956 & - \\
{$\left[\mathrm{MoO}_{2}(\mathrm{HL}) \mathrm{Cl}_{2}\right](4)$} & 3429 & 1584 & 1454 & 942 & 908 \\
{$\left[\mathrm{MoO}_{2}(\mathrm{HL})\left(\mathrm{NCS}_{2}\right](5)\right.$} & 3436 & 1590 & 1448 & 936 & 910 \\
{$\left[\mathrm{MoO}_{2}(\mathrm{HL}) \mathrm{Cl}\left(\mathrm{NO}_{3}\right)\right](6)$} & 3444 & 1582 & 1450 & 938 & 906 \\
\hline
\end{tabular}


and ${ }^{2} \mathrm{~B}_{2} \rightarrow^{2} \mathrm{~A}_{1}\left(d x y \rightarrow d z^{2}\right)$ transitions respectively. ${ }^{22}$ All the complexes show a medium intensity band in the range $480-500 \mathrm{~nm}$ and a weak broad band in the range 650-710 $\mathrm{nm}$. However, we could not locate the third band in these complexes, probably due to the mask by high intensity charge transfer transitions. The electronic spectra thus indicate an octahedral environment for all the complexes and are in conformity with Ballhausen-Gray scheme for an octahedral geometry. ${ }^{23}$ The complexes are best considered as octahedral with strong tetragonal distortion, resulting from $\mathrm{MoO}$ bond. ${ }^{24}$

\section{${ }^{1}$ H NMR Spectra}

The ${ }^{1}$ H NMR spectra of (HL) (Fig. 2) and the complex 4 were recorded. The ${ }^{1} \mathrm{H}$ NMR spectrum ${ }^{25}$ of the free ligand HL showed a sharp signal at $\delta 12.505 \mathrm{ppm}$ characteristic

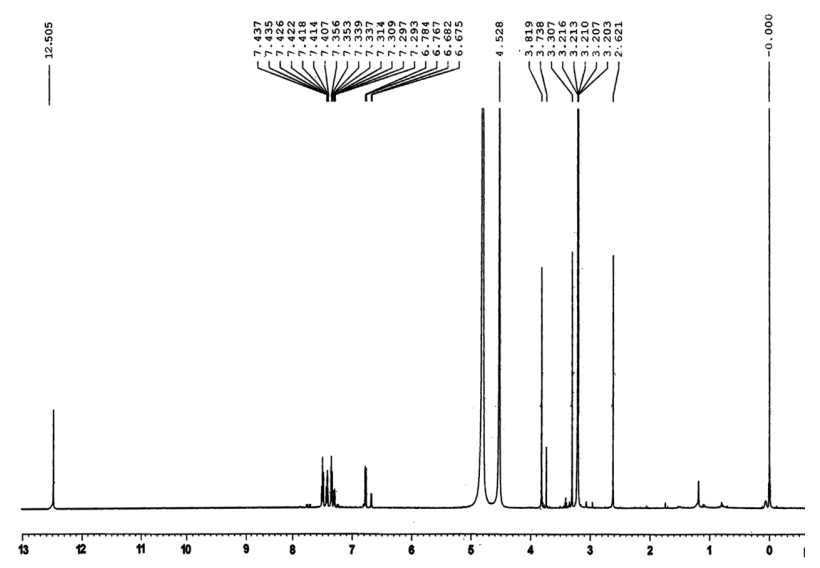

Fig. 2. ${ }^{1} \mathrm{H}$ NMR spectrum of HL. of the phenolic $\mathrm{OH}$ proton. The spectrum displays three singlets, which correspond to methyl protons. The $>\mathrm{C}-\mathrm{CH}_{3}$ group of pyrazolone ring appears as a sharp singlet in the region $\delta 2.62 \mathrm{ppm}$ while the $>\mathrm{N}-\mathrm{CH}_{3}$ signal is observed as another singlet in the region $\delta 3.30 \mathrm{ppm}$ and $-\mathrm{OCH}_{3}$ signal is observed at $\delta 3.82 \mathrm{ppm}$. The signal due to five aromatic protons of the antipyrine phenyl ring appear as multiplet between $\delta$ (7.29-7.44 ppm) and these due to the protons of phenyl rings are observed as multiplet between $\delta(6.67-$ $6.78 \mathrm{ppm})$. On analyzing the spectrum of $\left[\mathrm{MoO}_{2}(\mathrm{HL}) \mathrm{Cl}_{2}\right]$, the presence of singlet due to phenolic proton indicates the non participation of the - $\mathrm{OH}$ group during coordination, which is further confirmed by the IR spectra.

\section{EPR Spectra}

EPR spectra of the complexes provide information about the coordination environment around the metal ion in the complexes. The X-band EPR spectrum of complex 1 recorded in the polycrystalline state at LNT is given in Fig. 3. The ESR spectrum of the complex exhibits an isotropic spectrum with $\mathrm{g}_{\text {iso }} \sim 1.93 \mathrm{G}$.

Seventy-five percent of molybdenum are isotopes ${ }^{94} \mathrm{Mo}$ and ${ }^{96} \mathrm{Mo}$ with the nuclear spin quantum number $\mathrm{I}=0$, and these isotopes give one ESR line. The natural abundance of ${ }^{95} \mathrm{Mo}$ and ${ }^{97} \mathrm{Mo}$ is $15.78 \%$ and $9.60 \%$, respectively, both with a nuclear spin $\mathrm{I}=5 / 2$. Thus, each isotope should give six ESR lines. ${ }^{95} \mathrm{Mo}$ overlaps with the six lines arising from ${ }^{97} \mathrm{Mo}$, and only six broad lines are observed in addition to the single central line originating from ${ }^{94} \mathrm{Mo}$ and ${ }^{96} \mathrm{Mo}$. This hyperfine splitting may

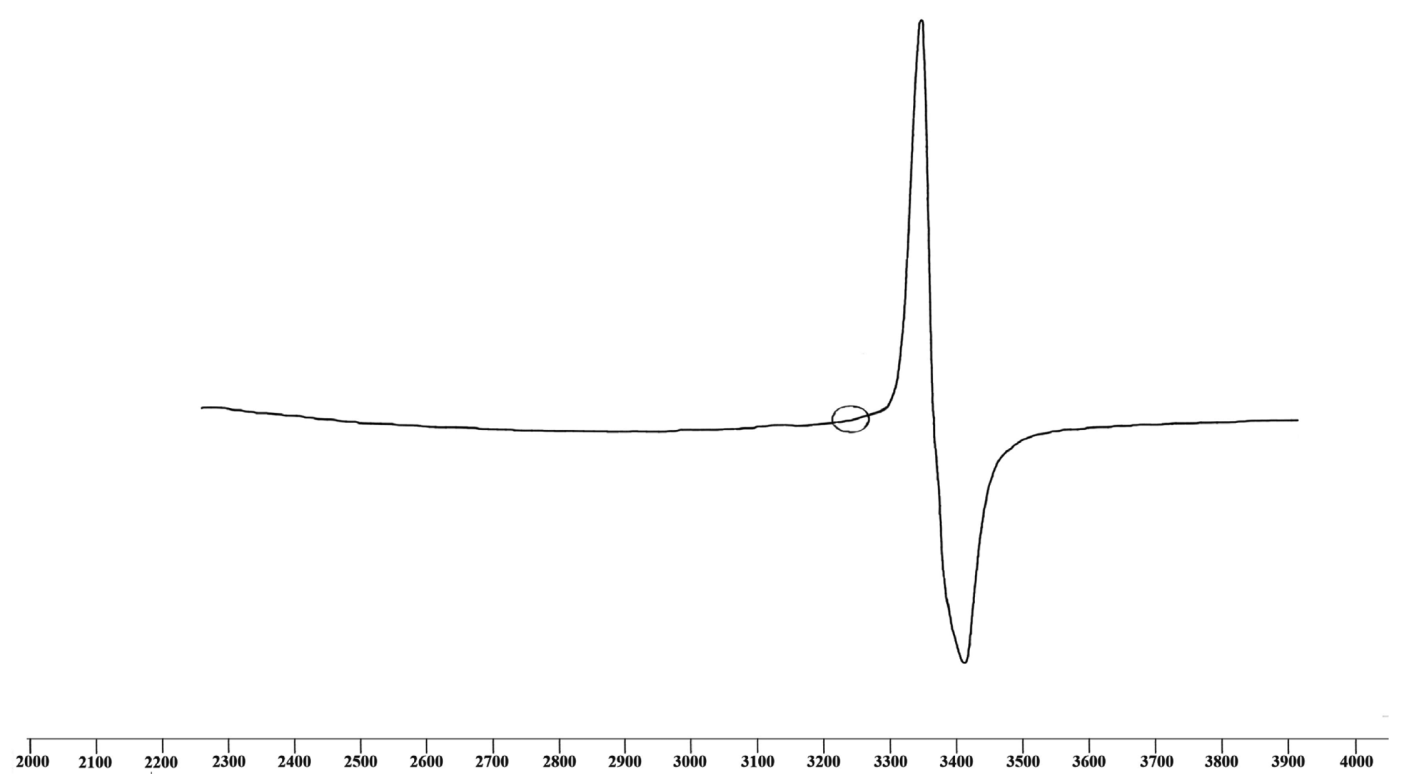

Fig. 3. EPR spectrum of complex $\left[\mathrm{MoO}(\mathrm{HL}) \mathrm{Cl}_{3}\right]$. 


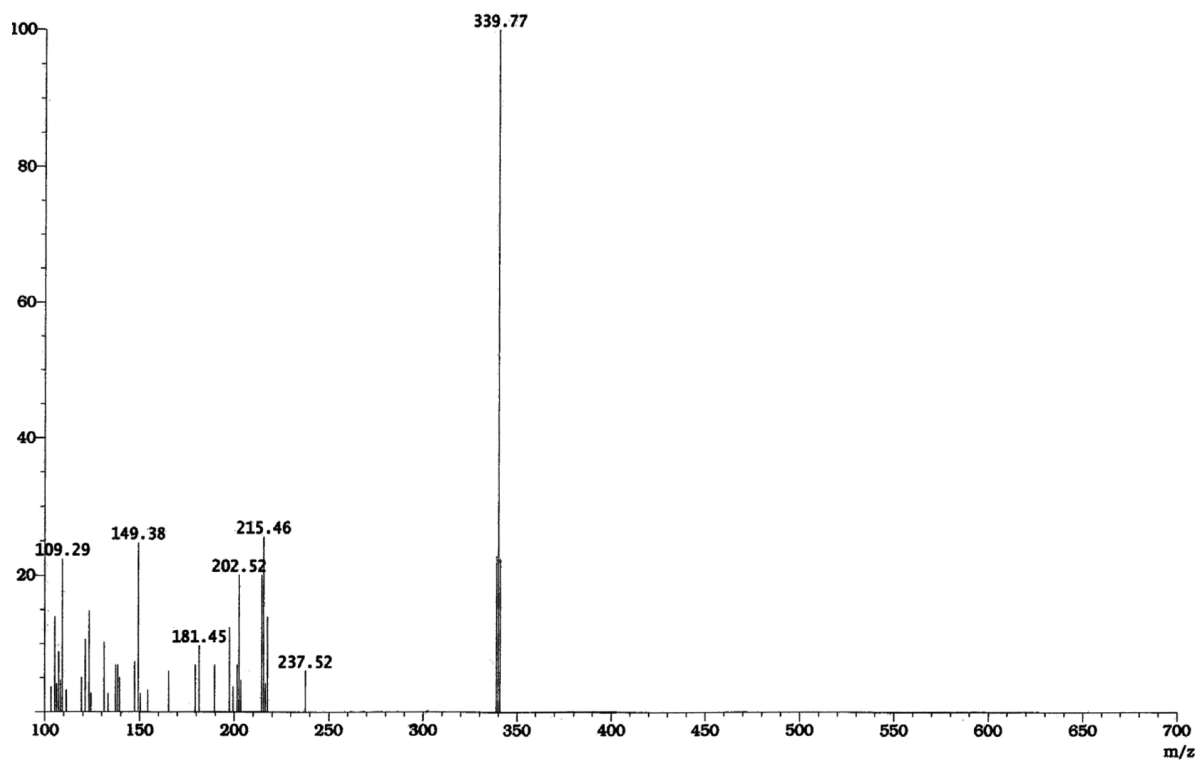

Fig. 4. FAB mass spectrum of HL.

not be seen if there is signal broadening due to spin lattice relaxation and spin-spin interaction. ${ }^{14}$ In the present case the isotropic nature of the spectrum is attributable to enhanced spin lattice relaxation and spin -spin interaction, moreover the spectrum is recorded in a magnetically concentrated medium. ${ }^{26}$ Absence of half field signal in the EPR spectrum rules out any metal-metal interaction in the complex.

In the octahedral complexes of molybdenum $(\mathrm{V})$, the single electron located in $d_{x y}$ orbital. This orbital is related to other four $\mathrm{d}$ orbitals by rotations about one or other of the cartesian axes. If the rotation moves the electron into a vacant orbital, then the current resulting from the circulation leads to a magnetic field that opposes the applied field. Consequently the larger laboratory field is required to meet the Zeeman conditions and the calculated $g$ value will be smaller than the free electron. ${ }^{27}$

\section{FAB Mass Spectra}

Mass spectroscopy, which is mainly applied in the analysis of biomolecules, has been increasingly used as a powerful structural characterization technique in coordination chemistry. The FAB mass spectra of the ligand HL (Fig. 4) and its complexes $\mathbf{1}$ and $\mathbf{4}$ were recorded and their stoichiometric compositions were compared. The molecular ion peak $[\mathrm{M}+\mathrm{H}]^{+}$for ligand $\left(\mathrm{C}_{18} \mathrm{H}_{18} \mathrm{~N}_{4} \mathrm{O}_{3}\right)$, is at 339.77 . The complexes $\mathbf{1}$ and $\mathbf{4}$ show molecular ion peaks at $\mathrm{m} / \mathrm{z}$ 556.16 and 537.21 respectively, suggesting the complexes to be monomeric.

\section{Thermal Studies}

Thermal behavior of the complexes $\mathbf{1}$ and $\mathbf{5}$ were studied by TGA and DTG techniques by heating in air at a rate of $10^{\circ} \mathrm{C}$ per min. TG and DTG curves of complexes 1 and 4 were shown in Figs. 5 and 6, respectively.

The decomposition of the complex 1 takes place in three stages as indicated by the DTG peaks at $204{ }^{\circ} \mathrm{C}, 336^{\circ} \mathrm{C}$ and $639^{\circ} \mathrm{C}$. The stability range was extended from ambient temperature to $170{ }^{\circ} \mathrm{C}$. The initial mass loss $1-2 \%$ may be due to the desorption of moisture.First decomposition stage starts at $170{ }^{\circ} \mathrm{C}$ and ended at $230{ }^{\circ} \mathrm{C}$. The mass loss of $6.37 \%$ (calc. $6.43 \%$ ) is assigned to the loss of one mole of chlorine atom. The second stage decomposition ranged from $270{ }^{\circ} \mathrm{C}$ to $410{ }^{\circ} \mathrm{C}$. The weight loss at this stage was $43.8 \%$ and this stage could not be assigned to any specific decomposition. After this stage, weight loss takes place

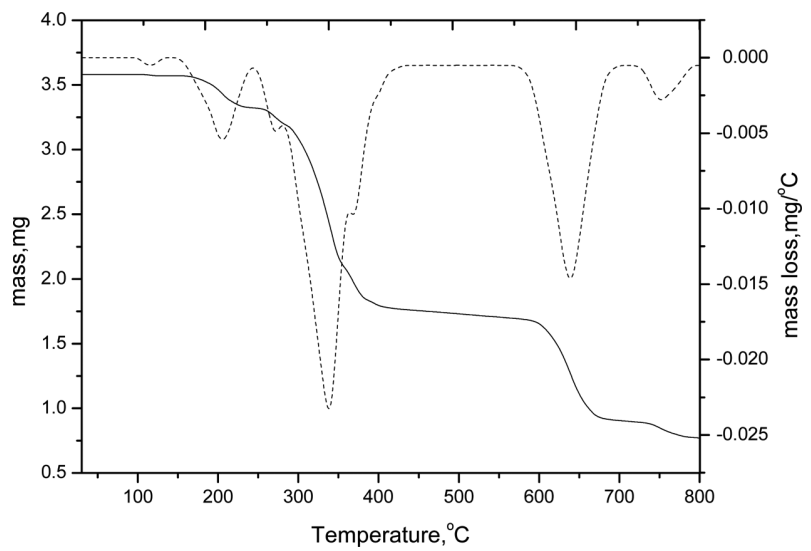

Fig. 5. $\mathrm{TG}$ and $\mathrm{DTG}$ curves of $\left[\mathrm{MoO}(\mathrm{HL}) \mathrm{Cl}_{3}\right]$. 


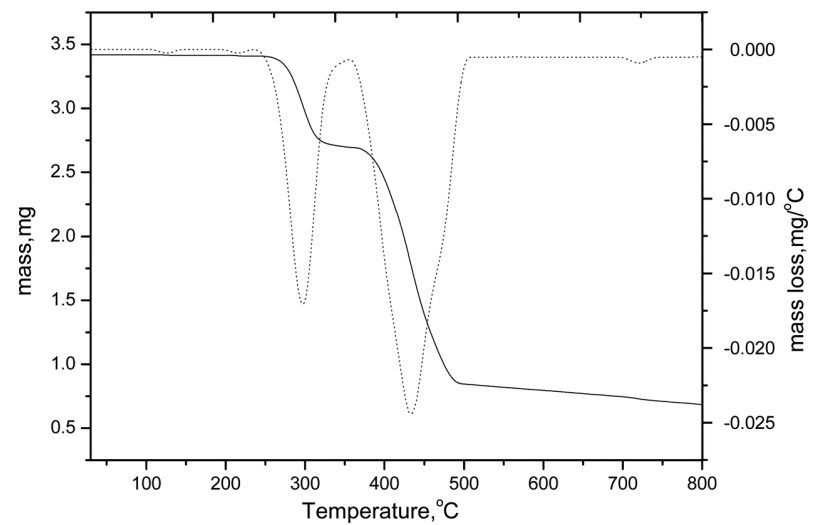

Fig. 6. $\mathrm{TG}$ and $\mathrm{DTG}$ curves of $\left[\mathrm{MoO}_{2}(\mathrm{HL})(\mathrm{NCS})_{2}\right]$. slowly and continuosly.The sample showed another weight loss in the region $590-680^{\circ} \mathrm{C}$. The weight loss in this stage was $24.07 \%$ (calc. $24.52 \%$ ) ascribed to the oxidative decomposition of the remaining part of the complex to give $\mathrm{MoO}_{3}$ as the ultimate residue. The weight of the sample at $680{ }^{\circ} \mathrm{C}$ was consisitent with the formation of $\mathrm{MoO}_{3}$. The sample showed another weight loss in the region 740$790{ }^{\circ} \mathrm{C}$. This may be due to the volatilization of $\mathrm{MoO}_{3}$ above $740{ }^{\circ} \mathrm{C} .^{28,29}$

The thermal decomposition of the complex 5 occurred in two stages as denoted by the DTG peaks at 297and $434{ }^{\circ} \mathrm{C}$. The complex is stable upto $260^{\circ} \mathrm{C}$. The first stage decomposition starts at $260{ }^{\circ} \mathrm{C}$ and is completed at $330{ }^{\circ} \mathrm{C}$.
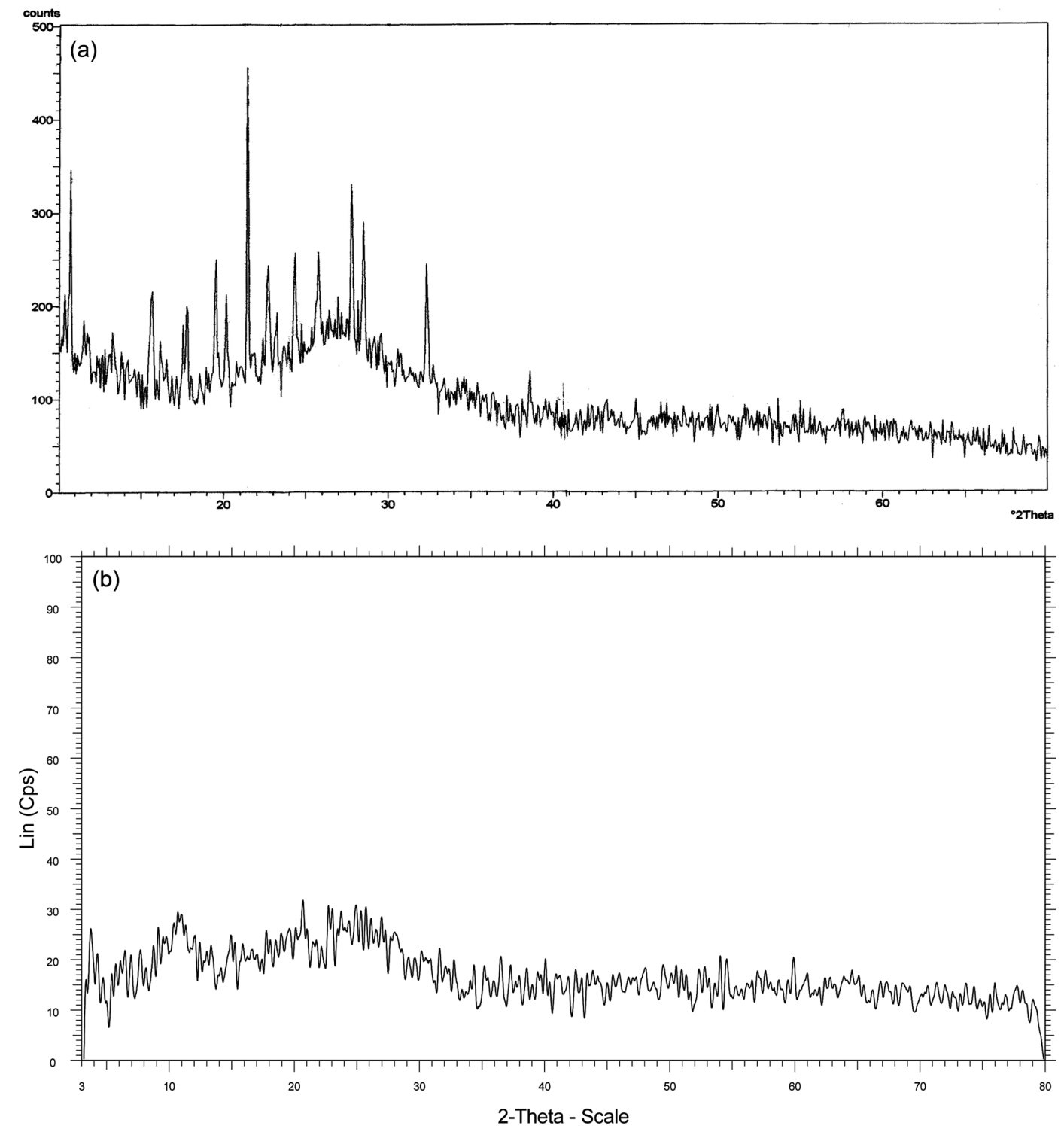

Fig. 7. (a) X-ray powder diffraction pattern of $\left[\mathrm{MoO}(\mathrm{HL}) \mathrm{Cl}_{3}\right]$ before irradiation, (b) X-ray powder diffraction pattern of $\left[\mathrm{MoO}(\mathrm{HL}) \mathrm{Cl} \mathrm{l}_{3}\right]$ after irradiation. 
The mass loss of $20.47 \%$ (calc. $19.95 \%$ ) corresponded to the loss of anionic part of the complex. The second stage decomposition ranges from $380^{\circ} \mathrm{C}$ to $490^{\circ} \mathrm{C}$. The weight loss at this stage was $54.68 \%$ (calc. $55.86 \%$ ). The weight of the sample at $490{ }^{\circ} \mathrm{C}$ was consistent with the formation of $\mathrm{MoO}_{3}$ formed by the oxidative decomposition of the complex.

\section{Irradiation Studies}

$\mathrm{X}$-ray diffraction and surface morphology of the complexes $\left[\mathrm{MoO}(\mathrm{HL}) \mathrm{Cl}_{3}\right]$ and $\left[\mathrm{MoO}_{2}(\mathrm{HL}) \mathrm{Cl}_{2}\right]$ were studied before and after gamma irradiation.

\section{Colour}

No colour change occurred upon irradiation indicating the absence of colour centers in the sample.

\section{X-ray Diffraction Studies}

$\mathrm{X}$-ray diffractograms for the unirradiated and irradiated samples of $\left[\mathrm{MoO}(\mathrm{HL}) \mathrm{Cl}_{3}\right]$ and $\left[\mathrm{MoO}_{2}(\mathrm{HL}) \mathrm{Cl}_{2}\right]$ are given in Figs. 7a, 7b, 8a \& 8b, respectively. XRD patterns are indexed using Hesse and Lipson's procedure. ${ }^{30}$ Lattice constants and lattice parameters are listed in Table 3 and the X-ray diffraction data are presented in Tables 4 \& 5 .

Lattice imperfections caused by irradiation influence
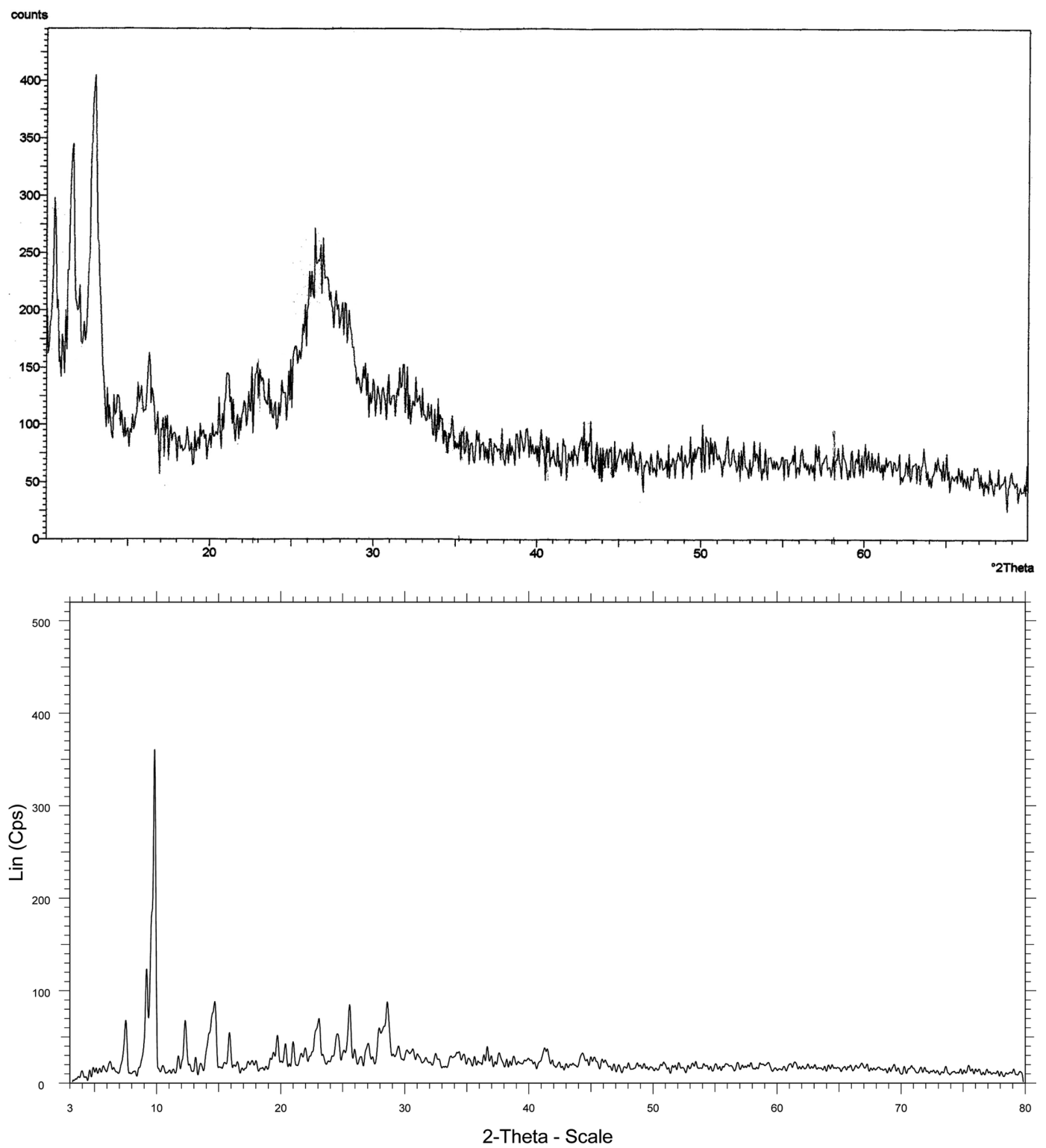

Fig. 8. (a) X-ray powder diffraction pattern of $\left[\mathrm{MoO}_{2}(\mathrm{HL}) \mathrm{Cl}_{2}\right]$ before irradiation, (b) X-ray powder diffraction pattern of $\left[\mathrm{MoO}_{2}\right.$ $(\mathrm{HL}) \mathrm{Cl}_{2}$ ] after irradiation. 
Table 3. Lattice constants and lattice parameters

\begin{tabular}{|c|c|c|c|c|c|c|c|}
\hline \multirow{2}{*}{ Complexes } & \multicolumn{3}{|c|}{ Lattice Constants $(\AA)$} & \multicolumn{3}{|c|}{ Lattice parameters $(\AA)$} & \multirow{2}{*}{$\begin{array}{c}\text { Particle } \\
\text { size }(\mathrm{nm})\end{array}$} \\
\hline & $\mathrm{A}$ & $\mathrm{B}$ & $\mathrm{C}$ & $\mathrm{a}$ & $\mathrm{b}$ & $\mathrm{c}$ & \\
\hline$\left[\mathrm{MoO}(\mathrm{HL}) \mathrm{Cl}_{3}\right]$ Unirradiated & 0.009 & 0.020 & 0.016 & 8.12 & 5.44 & 6.08 & 40.33 \\
\hline$\left[\mathrm{MoO}_{2}(\mathrm{HL}) \mathrm{Cl}_{2}\right]$ Unirradiated & 0.0198 & 0.0133 & 0.009 & 5.47 & 6.67 & 8.11 & 23.9 \\
\hline$\left[\mathrm{MoO}_{2}(\mathrm{HL}) \mathrm{Cl}_{2}\right]$ Irradiated to $800 \mathrm{kGy}$ & 0.0044 & 0.00653 & 0.00715 & 11.60 & 9.52 & 9.10 & 24.1 \\
\hline
\end{tabular}

Table 4. XRD data of $\left[\mathrm{MoO}(\mathrm{HL}) \mathrm{Cl}_{3}\right]$

\begin{tabular}{cccc}
\hline \multicolumn{4}{c}{ Unirradiated $\left.\mathrm{MoO}(\mathrm{HL}) \mathrm{Cl}_{3}\right]$} \\
\hline $\operatorname{Sin}^{2} \theta$ (obs) & $\operatorname{Sin}^{2} \theta($ calc $)$ & hkl & Intensity \% \\
\hline 0.0086 & 0.009 & 100 & 68.14 \\
0.0238 & 0.025 & 101 & 33.40 \\
0.0287 & 0.029 & 110 & 46.85 \\
0.0345 & 0.036 & 011 & 100 \\
0.0442 & 0.045 & 111 & 46.74 \\
0.0495 & 0.052 & 201 & 46.06 \\
0.0576 & 0.056 & 210 & 60.10 \\
0.0605 & 0.064 & 002 & 55.03 \\
0.0774 & 0.073 & 102 & 42.95 \\
0.1091 & 0.105 & 121 & 14.12 \\
\hline
\end{tabular}

the X-ray diffraction pattern of a substance. In the present study it is observed that unit cell parameters changed upon irradiation. The intensities of powder lines and the cor- responding $2 \theta$ values are found to be different for the irradiated sample. The unirradiated $\left[\mathrm{MoO}(\mathrm{HL}) \mathrm{Cl}_{3}\right]$ was found to have orthorhombic lattice but the irradiated $\left[\mathrm{MoO}(\mathrm{HL}) \mathrm{Cl}_{3}\right]$ recorded only very few reflections and hence could not be indexed. This may be an indication of the amorphous nature of the complex. Both unirradiated and irradiated $\left[\mathrm{MoO}_{2}(\mathrm{HL}) \mathrm{Cl}_{2}\right]$ complexes are found to have orthorhombic lattice.

High energy of radiation may change the physical properties of materials. The changes are strongly dependent on the internal structure of the absorbed substance, the radiation energy and dose. ${ }^{31}$ The radiation may cause ionization or excitation of the electrons and possibly, displacement of atoms from their sites in the lattice of the solid. The size of the crystal may change due to the stress caused by irradiation. If the crystals are under uniform stress, a contraction of the unit cell occurs. The stress factor and structure fac-

Table 5. XRD data of $\left[\mathrm{MoO}_{2}(\mathrm{HL}) \mathrm{Cl}_{2}\right]$

\begin{tabular}{|c|c|c|c|c|c|c|c|}
\hline \multicolumn{4}{|c|}{ Unirradiated $\left.\mathrm{MoO}_{2}(\mathrm{HL}) \mathrm{Cl}_{2}\right]$} & \multicolumn{4}{|c|}{ Irradiated $\left.\mathrm{MoO}_{2}(\mathrm{HL}) \mathrm{Cl}_{2}\right]$} \\
\hline $\operatorname{Sin}^{2} \theta$ (obs) & $\operatorname{Sin}^{2} \theta$ (calc) & hkl & Intensity \% & $\operatorname{Sin}^{2} \theta$ (obs) & $\operatorname{Sin}^{2} \theta$ (calc.) & hkl & Intensity \% \\
\hline 0.00845 & 0.009 & 001 & 67.74 & 0.00419 & 0.0044 & 100 & 18.4 \\
\hline 0.01265 & 0.0133 & 010 & 100 & 0.00630 & 0.00653 & 010 & 33.9 \\
\hline 0.01991 & 0.0198 & 100 & 24.7 & 0.00723 & 0.00715 & 001 & 100 \\
\hline 0.03327 & 0.033 & 110 & 20.62 & 0.01134 & 0.01155 & 101 & 18.4 \\
\hline 0.04198 & 0.042 & 111 & 51.78 & 0.015 & 0.01368 & 011 & 13 \\
\hline 0.0397 & 0.036 & 002 & 17.11 & 0.01619 & 0.0176 & 200 & 24.1 \\
\hline 0.0766 & 0.073 & 120 & 13.55 & 0.01889 & 0.01808 & 111 & 14.8 \\
\hline 0.10172 & 0.1015 & 211 & 82.77 & 0.02921 & 0.0305 & 120 & 13.9 \\
\hline \multirow[t]{13}{*}{0.18085} & 0.1782 & 300 & 4.08 & 0.03115 & 0.03128 & 211 & 11.4 \\
\hline & & & & 0.03618 & 0.03513 & 012 & 10.1 \\
\hline & & & & 0.03304 & 0.033 & 102 & 12 \\
\hline & & & & 0.0388 & 0.03767 & 122 & 15.2 \\
\hline & & & & 0.03920 & 0.03953 & 112 & 16 \\
\hline & & & & 0.03957 & 0.0396 & 300 & 17.7 \\
\hline & & & & 0.04517 & 0.04613 & 310 & 14.4 \\
\hline & & & & 0.05457 & 0.05328 & 311 & 11.5 \\
\hline & & & & 0.05815 & 0.05877 & 030 & 16.1 \\
\hline & & & & 0.059183 & 0.05912 & 122 & 15.5 \\
\hline & & & & 0.06468 & 0.06435 & 003 & 10.7 \\
\hline & & & & 0.09882 & 0.09837 & 330 & 10.5 \\
\hline & & & & 0.12419 & 0.12312 & 033 & 10.1 \\
\hline
\end{tabular}


tor are responsible for the overall change in the intensity of diffraction lines, crystallite size and unit cell parameters. $^{32}$

The particle sizes calculated using Scherer equation, $d=$ $B \lambda / \beta \cos \theta$, (where $d, B, \lambda, \beta$ and $\theta$ are the particle diameter, in $\AA$, of the crystalline phase, Scherer constant (0.9), wavelength of X-ray beam (1.5439 §), FWHM (Full Width Half Maximum) of the main diffraction line of XRD and its diffraction angle, respectively).

\section{Surface Morphology}

SEM micrographs of the ligand, unirradiated and irradiated samples of $\left[\mathrm{MoO}(\mathrm{HL}) \mathrm{Cl}_{3}\right]$ and $\left[\mathrm{MoO}_{2}(\mathrm{HL}) \mathrm{Cl}_{2}\right]$ are given in Fig. 9. Changes in the scanning electron micrographs indicate that the applied dose can cause changes in the surface morphology of crystals.

The SEM micrograph of the ligand as shown in Fig. 9(a) reveal an amorphous nature for the ligand. The SEM images of the unirradiated $\left[\mathrm{MoO}(\mathrm{HL}) \mathrm{Cl}_{3}\right]$ and $\left[\mathrm{MoO}_{2}\right.$ (HL) $\mathrm{Cl}_{2}$ ] complexes of the ligand given in Figs. 9(b), (c), (e) and (f), respectively exhibit significant change in morphology upon complex formation. The SEM image of the unirradiated $\left[\mathrm{MoO}(\mathrm{HL}) \mathrm{Cl}_{3}\right]$ (Figs. 9b \& 9c) shows the presence of micro rods and micro spheres, the diameter of which is less than $2 \mu \mathrm{m}$. The SEM image at lower resolutions of the unirradiated $\left[\mathrm{MoO}_{2}(\mathrm{HL}) \mathrm{Cl}_{2}\right]$ complex (Fig. 9e) distinctly reveal the formation of micro rods with an average diameter of approximately $2 \mu \mathrm{m}$. Higher resolutions of this complex show the presence of nano spheres on the surface of the microrods.

Figs. 9(d) and (g) depict the SEM images of the $[\mathrm{MoO}$ $\left(\mathrm{HL} \mathrm{Cl}_{3}\right]$ and $\left[\mathrm{MoO}_{2}\left(\mathrm{HL} \mathrm{Cl}_{2}\right]\right.$ complexes after $\gamma$ irradiation. Irradiation of the complexes with $\gamma$ rays have brought about noticeable changes in the particle size and morphology of the samples. The oxomolybdenum (V) complex have crystals with well defined edges and exhibits
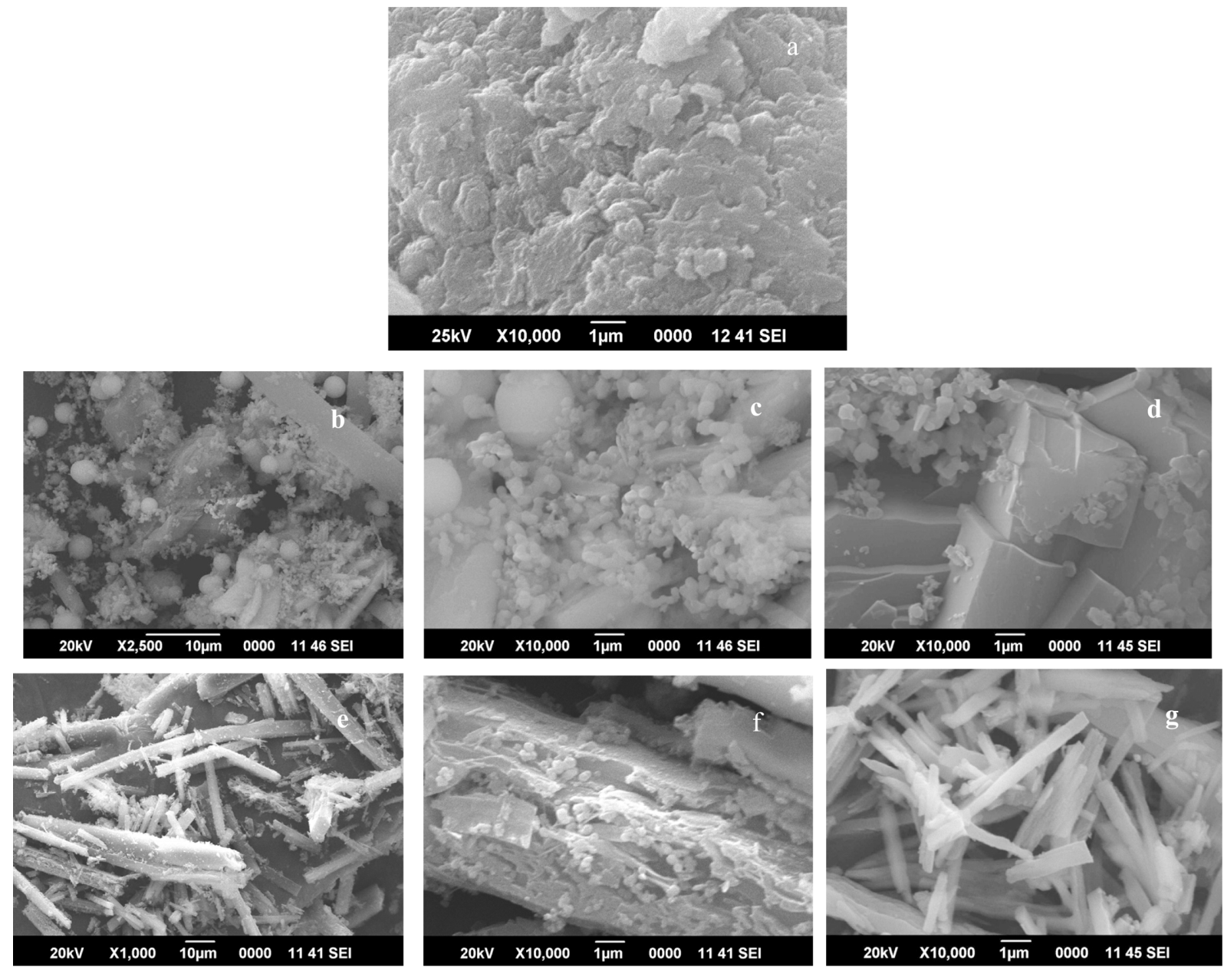

Fig. 9. SEM Micrographs of ligand and complexes. 9a Ligand, 9b \& c $\left[\mathrm{MoO}(\mathrm{HL}) \mathrm{Cl}_{3}\right]$ before irradiation, $9 \mathrm{~d}\left[\mathrm{MoO}(\mathrm{HL}) \mathrm{Cl}_{3}\right]$ after irradiation, $9 \mathrm{e} \& \mathrm{f}\left[\mathrm{MoO}_{2}(\mathrm{HL}) \mathrm{Cl}_{2}\right]$ before irradiation, $9 \mathrm{~g}\left[\mathrm{MoO}_{2}(\mathrm{HL}) \mathrm{Cl}_{2}\right]$ after irradiation. 
<smiles>[X][C@@H](/N=N/c1c(C)n(C)n(-c2ccccc2)c1=O)OC</smiles>

Fig. 10. Proposed 2D structure of $\left[\mathrm{MoO}(\mathrm{HL}) \mathrm{XCl}_{2}\right]$.

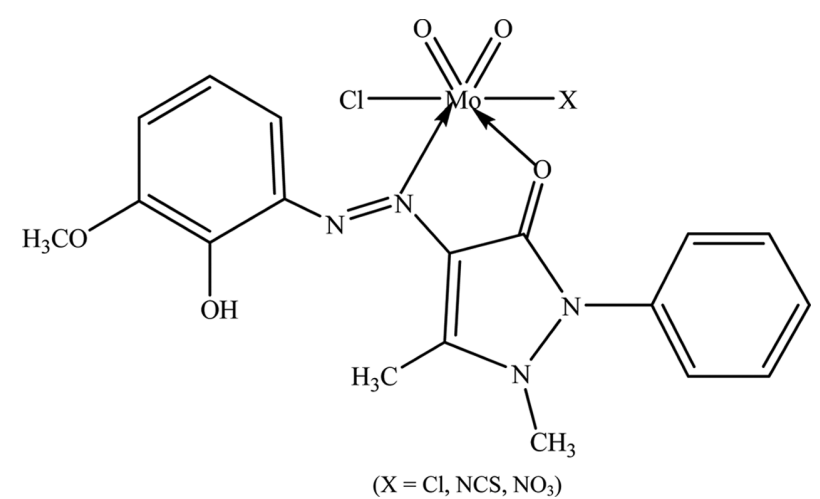

Fig. 11. Proposed 2D structure of $\left.\mathrm{MoO}_{2}(\mathrm{HL}) \mathrm{XCl}\right]$.

some degree of aggregation. On the other hand, the nano spheres seen on the surface of the micro rods of dioxomolybdenum (VI) complex have completely vanished and the complex achieve a rod or stick shape with prismatic geometry. Moreover the length of the rods has been brought down to less than that before irradiation. The diameter or thickness of the rods has been reduced to less than $300 \mathrm{~nm}$ after $\gamma$ irradiations. The results clearly indicate that $\gamma$ irradiation has a vital effect in tuning the size and morphology of the synthesized complexes.

\section{Antimicrobial Study}

The ligand and complexes were not active against $M$. tuberculosis H37Rv, E. coli and Lactobacillus leichmannii.

Thus on the basis of the spectral data and physicochemical studies, a distorted octahedral geometry (Figs. 10 and 11) has been tentatively proposed for all the complexes.

\section{CONCLUSION}

The synthesis and characterization of octahedral oxomolybdenum (V) and dioxomolybdenum (VI) complexes with bidentate chelating ligand are reported. From the spectroscopic, analytical and thermal analysis data, it can be concluded that the molybdenum existed in a distorted octahedral environment with the ligand. The FAB mass and EPR spectral data suggest monomeric nature of the complexes. X-ray diffraction study revealed that unit cell parameters have changed upon irradiation. SEM study showed that $\gamma$ irradiation have impact on the size and morphology of the synthesized complexes.

Acknowledgements. The authors are thankful to NIIST, Thiruvananthapuram, STIC, Kochi, and Department of Chemistry, University of Kerala, Thiruvananthapuram, SAIF, I.I.T. Bombay for the facilities provided for the above studies and analysis. We are grateful to the authorities of the Rubber Board, Kottayam, Government of India, for providing facilities for $\gamma$-irradiation.

\section{REFERENCES}

1. Dhavan, T. K.; Enemark, J. H. Inorg. Chem. 1996, 35, 4873 .

2. Jeyakumar, K. D.; Chand, K. J. Chem. Sci. 2009, 121, 111.

3. Harikumaran Nair, M. L.; Thankamani, D. Russ. J. Coord. Chem. 2010, 36, 259.

4. Da Costa, A. P.; Reis, P. M.; Gamelas, C.; Romão, C. C.; Royo, B. Inorg. Chim. Acta 2008, 361, 1915.

5. Arnáiz, F. J.; Guado, R. A.; Pedrosa, M. R.; Maestro, M. A. Polyhedron 2004, 23, 537.

6. Wong, Y.; Cowley, A. R.; Dilworth, J. R. Inorg. Chim. Acta 2004, 357, 4358.

7. Burgmayer, S. J. N.; Stiefel, E. I. J. Chem. Edu. 1985, 62, 943.

8. Prathapachandra Kurup, M. R.; Seena, E. B. Polyhedron 2007, 26, 3595.

9. Harikumaran Nair, M. L.; Thankamani, D. Indian J. Chem. 2009, 48A, 1212.

10. El-Shobaky, H. G.; El-Mohsen, M. T. J. Radioanal. Nucl. Chem. 2002, 254, 151.

11. Krishnan, G.; Jayashri, T. A. J. Radioanal. Nucl. Chem. 2008, 277, 693.

12. Zidan, A. S. A.; El-Said A. I.; El-Meligy, M. S.; Aly, A. A. M.; Mohammed, O. F. J. Therm. Anal. Calorim. 2000, $62,665$.

13. Vogel, A. I. A text book of Quantitative Inorganic Analysis; John Wiley and Sons: New York, 1963.

14. Dutta, R. L.; Syamal, A. Elements of Magneto Chemistry; East West Press: New Delhi, India, 1992.

15. Harikumaran Nair, M. L.; Sheela, A. Indian J. Chem. 2008, 47(A), 1787.

16. Harikumaran Nair, M. L.; Siji, V. L. J. Indian Chem. Soc. 2009, 86, 441.

17. Figgis, B. N. Introduction to Ligand Fields; Interscience- 
John Wiley: New York, 1966.

18. Harikumaran Nair, M. L.; Prabhakaran, C. P. Indian J. Chem. 1998, 37(A), 452.

19. Gupta, N.; Singh, R. V. Indian J. Chem. 1998, 37(A), 75.

20. Nakamoto, K. Infrared and Raman Spectra of Inorganic and Coordination Compounds; Wiley \& Sons: New York, 1978.

21. Prathapachandra Kurup, M. R.; Mangalam, N. A. Spectrochim. Acta 2009, 71, 2040.

22. Lever, A. B. P. Inorganic Electronic Spectroscopy; Elsevier: New York, 1984.

23. Ballhausen, C. J.; Gray, H. B. Molecular Orbital Theory; Benjamin: New York, 1965.

24. Harikumaran Nair, M. L.; Thankamani, D. J. Ind. Chem. Soc. 2010, 87, 1029.

25. Mandlik, P.; More, M. B.; Aswar, A. S. Indian J. Chem.
2003, 42, 1064.

26. Bindu, P.; Prathapachandra Kurup, M. R.; Satyakeerty, T. R. Polyhedron 1998, 18, 321.

27. Que Lawrence Physical Methods in Bioinorganic Chemistry-Spectroscopy and Magnetism; University Science Books-Saulsalifo: California, 2000.

28. Soria, D. B.; Barqui, M.; Gonzalez, M. J.; Garmendia, Estiu, G. J. Coord. Chem. 2008, 61, 3815.

29. Sridevi, N.; Yusuff, K. K. M. Indian J. Chem. 2008, 47(A), 836.

30. Lipson, H.; Steeple, H. Interpretation of X-ray Powder Diffraction Patterns; Macmillan: London, 1979.

31. Lemine, O. M.; Alharbi, A.; Bououdina, M.; Alamry, S.; Kh. Ziq. Univ. Sharjah J. Pure Appl. Sci. 2008, 5, 26.

32. Krishnan, G; Jayashri, T. A.; Sudha, P. Radiat. Phys. Chem. 2009, 78, 933. 